\title{
Domestic processing and storage on the physical-chemical characteristics of acerola juice (Malpighia glabra L.).
}

\section{Processamento doméstico e armazenamento nas características físico-químicas de suco de acerola (Malpighia glabra L.).}

\author{
Bruno Martins Dala-Paula1*(D), Taís Pereira dos Santos' ${ }^{1}$, Laura de Souza Araújo1 (D), \\ Renata Rosane Andrade Bastos ${ }^{1}$ (D) Juliana de Oliveira Moraes ${ }^{1}$ (D) Nádia Carbonera² ${ }^{2}$
}

'Universidade Federal de Alfenas/UNIFAL, Alfenas, MG, Brasil

${ }^{2}$ Universidade Federal de Pelotas/UFPEL, Centro de Ciências Químicas, Farmacêuticas e de Alimentos, Pelotas, RS, Brasil

*Corresponding author: bruno.paula@unifal-mg.edu.br

Received in September 9, 2019 and approved in November 6, 2019

\begin{abstract}
Acerola is a tropical fruit that stands out for its high content of ascorbic acid and phenolic compounds. However, there is currently a lack of information on the effects of the preparation and domestic storage of fruit juices, especially that of acerola. The objective of this work was to evaluate the effect of different liquefying times (10, 30 and $50 \mathrm{~s}$ ) and cold storage at $4{ }^{\circ} \mathrm{C}$ for $0,24,48$ and $72 \mathrm{~h}$ in domestic acerola juice. In relation to such, physicochemical determinations were performed, including $\mathrm{pH}$, total titratable acidity, antioxidant potential, contents of phenolic compounds and total flavonoids in juices produced from the whole fruit, the pulp and acerola seed extracts. Whole fruit juice, liquefied for $10 \mathrm{~s}$, had the highest $\mathrm{pH}$ and lowest acidity averages $(P \leq 0.05)$. The contents of phenolic and flavonoid compounds ranged from $26.06 \pm 1.18$ to $168.34 \pm 24.63 \mathrm{mg}$ of gallic acid equivalents (GAE)/100 $\mathrm{mL}$ and $11.17 \pm 0.96$ to $49.45 \pm 1.43 \mathrm{mg}$ of catechin equivalents $(\mathrm{CE}) / 100 \mathrm{~mL}$, respectively. Total phenolics were higher in whole acerola juices and total flavonoids in seed extracts, both when liquefied for $50 \mathrm{~s}$. The antioxidant potential ranged from $0.12 \pm 0.01$ to $4.26 \pm 0.78 \mathrm{mmol}$ of Trolox equivalents (TE)/100 mL, and was also higher in whole acerola juice, liquefied for $50 \mathrm{~s}(P \leq 0.05)$. The results showed that acerola pulp has higher phenolic content and antioxidant potential, while seeds have more flavonoids. The liquefying time of the whole fruit for $50 \mathrm{~s}$ and consumption during the first $24 \mathrm{~h}$, were the best conditions tested in this study, for obtaining a juice with a high content of phenolic and antioxidant activity.
\end{abstract}

Index terms: Antioxidant potential; phenolic compounds; flavonoids.

\begin{abstract}
RESUMO
A acerola é uma fruta tropical que se destaca pelo alto teor de ácido ascórbico e compostos fenólicos. No entanto, atualmente há carência de informações sobre os efeitos do preparo e armazenamento doméstico de sucos de frutas, em especial de acerola. 0 presente trabalho teve por objetivo avaliar no suco de acerola doméstico, o efeito de diferentes tempos de liquidificação (10, 30 e $50 \mathrm{~s}$ ) e do armazenamento refrigerado a $4{ }^{\circ} \mathrm{C}$, por $0,24,48$ e $72 \mathrm{~h}$. Relacionado a isto, foram executadas determinações físico-químicas, compreendendo, $\mathrm{pH}$, acidez titulável total, potencial antioxidante, teores de compostos fenólicos e flavonoides totais em sucos produzidos com a fruta inteira, somente com a polpa e em extratos de sementes de acerola. Os sucos das frutas inteiras, liquidificados por $10 \mathrm{~s}$, apresentaram as maiores médias de $\mathrm{pH}$ e menores de acidez $(P \leq 0,05)$. Os teores de compostos fenólicos e flavonoides variaram

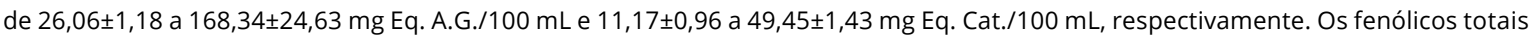
foram superiores nos sucos de acerolas inteiras e os flavonoides totais nos extratos de sementes, ambos liquidificados por $50 \mathrm{~s}$. O potencial antioxidante variou de $0,12 \pm 0,01$ a $4,26 \pm 0,78 \mathrm{mmol}$ de trolox/100 mL, sendo também superior nos sucos de acerolas inteiras, liquidificadas por $50 \mathrm{~s}(P \leq 0,05)$. Os resultados demonstraram que a polpa de acerola possui maior teor de fenólicos e potencial antioxidante, enquanto as sementes, flavonoides. O tempo de liquidificação da fruta inteira por 50 s e o consumo imediato ou durante as primeiras $24 \mathrm{~h}$ foram as melhores, dentre as condições testadas neste estudo, a fim de se obter um suco com elevado conteúdo de compostos fenólicos e atividade antioxidante.
\end{abstract}

Termos para indexação: Potencial antioxidante; compostos fenólicos; flavonoides. 


\section{INTRODUCTION}

Acerola is a tropical fruit native to Central America and northern South America, belonging to the family Malpighiaceae Juss. Among the species of this fruit, two (Malpighia glabra L and Malpighia emarginata Sessé \& Moc. ex. DC.) have been commonly cultivated for consumption and marketing, especially in Brazil, Mexico and certain parts of South East Asia and India (Belwal et al., 2018). The cultivation of acerola trees in Brazil began with the importing of seeds from Puerto Rico in the 1950s. The Antillean fruit has already been considered as a hybrid of the species M. glabra L. and M. punicifolia, the former coming from a small tree and the latter from a bush (Simão, 1971).

In a study published by Gomes et al. (2001), the authors report that the names M. glabra L. and M. punicifolia are synonyms applied to a different species of acerola and point out that the proper use of the nomenclature to designate acerola should be M. emarginata. However, the Integrated Taxonomic Information System shows the current taxonomic status of M. glabra L. and M. emarginata Sessé \& Moc. ex. DC. as accepted, but M. punicifolia as misapplied, with a current status of unaccepted (Itis, 2019).

With the increasing interest in healthier life habits, the consumption of fruits with functional properties has become increasingly popular, besides being a fundamental component of a nutritionally balanced diet aimed at the prevention of chronic diseases. Acerola (Malpighia glabra) is a tropical fruit that stands out for its high content of ascorbic acid and phenolic compounds, in particular the flavonoids: rutin (Caetano; Daiuto; Vieites, 2012; Leffa et al., 2015), quercetin glycosides and kaempferol, the latter being the main flavonol present in ripe acerola (Vasavilbazo-Saucedo et al., 2018).

Phenolic compounds have known antioxidant activity related to their ability to chelate metals, inhibit lipoxygenase enzymes and capture and neutralize free radicals from hydrogen donation. The antioxidant potential of phenolic compounds is directly linked to the number and arrangement of hydroxyl groups, the extent of structural conjugation, as well as the electronic ring resonance (Ho; Rafi; Ghai, 2010; Gómez-Mejía et al., 2019). Due to these characteristics, several commercial products containing acerola have been used as a dietary supplement in the optimization of immune response, as a source of antioxidant compounds and to meet nutritional needs (Pereira et al., 2013; Belwal et al., 2018).
Brazil is the world's largest producer and exporter of acerola in natura or its pulp, a product developed in response to short fruit shelf life. In addition to this application, the fruit is widely used to produce acerola juice, a slightly acidic flavored beverage, usually consumed either pure or mixed with other fruits (Belwal et al., 2018). Acerola should be harvested when it is intensely red in color, yet still firm in consistency, in order to avoid losses during transport and handling. If the fruit is not frozen, it should be consumed as soon as possible because, after 24 hours, the fruit considerably loses its characteristics of freshness and quality (Corrêa et al., 2017).

In addition to the nutritional and sensory aspects, practicality remains an important factor of consumer desire and intention to purchase. Convenience, when attributed to fruit, is related to the ease of storage and preparation for the consumption of fresh fruit or juice. The processing of acerola affects its physicochemical, functional and even its nutritional characteristics. Maia et al. (2007) demonstrated that the industrial processing of juice increased the $\mathrm{pH}$ and carotenoid content and reduced the vitamin $\mathrm{C}$ and anthocyanin contents, keeping other evaluated parameters unchanged (total soluble solids, reducing and total sugars). In contrast, the processing, freezing and storage of fruit pulp, according to commercial practice for 11 months, did not significantly affect carotenoid contents, thus proving to be efficient for preservation (Agostini-Costa; Abreu; Rossetti, 2003).

The literature includes numerous scientific publications regarding the effects of different types of industrial processing on the physicochemical, nutritional and sensory characteristics of acerola (Chaves et al., 2004; Maia et al., 2007; Caetano; Daiuto; Vieites, 2012; Corrêa et al., 2017; Nascimento et al., 2018). However, there is currently a lack of information on the effects of the preparation and domestic storage of fruit juices, especially that of acerola. Thus, the present study aimed to evaluate the physicochemical characteristics of acerola juice through domestic preparation at different times of blending and throughout storage.

\section{MATERIAL AND METHODS}

The raw material used was acerola (Malpighia glabra L.) harvested in Alfenas-MG, Brazil (latitude: -21.43333 and longitude: -45.950000). Approximately $4 \mathrm{~kg}$ of acerola were harvested from different trees at maturity stages identified by the firmness of the pulp, through manual palpation, and completely red-colored bark, mixed and packed in polyethylene packaging. After 
harvesting, the fruits were transported at room temperature to the Experimental Nutrition Laboratory of the College of Nutrition of the Federal University of Alfenas - UNIFALMG, Brazil.

The fruits were sanitized in chlorinated water $(200$ ppm), then packaged in polyethylene containers, and then stored frozen at $-18{ }^{\circ} \mathrm{C}$ until use. For seed and pulp analysis, the fruits were manually pulped, with their seeds separated and washed in running water. Whole fruits and their parts (seeds and pulp) were separately liquefied with $30 \%(\mathrm{w} / \mathrm{v})$ distilled water, with $60 \mathrm{~g}$ of sample and 200 $\mathrm{mL}$ of water using an $800 \mathrm{w}$ Philco household blender, 60 $\mathrm{Hz}$, at power 1 (China). Extracts of whole fruits and their parts were prepared in triplicate for the different liquefying times $(10,30$ and $50 \mathrm{~s})$.

The juices were passed through a 20 mesh, 850 $\mu \mathrm{m}$ mesh opening sieve for domestic use and packed in $500 \mathrm{ml}$ clear glass containers with a lid. The juices obtained from whole fruits and pulp, as well as the seed extracts, were immediately analyzed (time $0 \mathrm{~h}$ ). The juices of whole acerola were then stored under refrigeration at $4{ }^{\circ} \mathrm{C}$ for $72 \mathrm{~h}$ while being analyzed again after 24,48 and $72 \mathrm{~h}$ of its preparation.

The $\mathrm{pH}$ determinations were performed in a Luca210 (Lucadema) potentiometer and the total titratable acidity was performed with $0.1 \mathrm{M}$ factorized $\mathrm{NaOH}$ titrating solution, according to the methodology published by AOAC (1995).

Total flavonoid analyses were performed according to the methodology proposed by Gómez-Mejía et al. (2019) with modifications. A $250 \mu \mathrm{L}$ aliquot of the filtered samples was added to $1.0 \mathrm{~mL}$ distilled water and $75 \mu \mathrm{L} \mathrm{NaNO}_{2}$ solution $(5 \% \mathrm{w} / \mathrm{v})$. After homogenization and $5 \mathrm{~min}$ incubation at room temperature, $75 \mu \mathrm{AlCl}_{3}(10 \% \mathrm{w} / \mathrm{v})$ was added, repeating the shaking and incubation process. Finally, $0.5 \mathrm{~mL} \mathrm{NaOH}(1 \mathrm{~mol} / \mathrm{L})$ was added, with the mixture homogenized and incubated again for $5 \mathrm{~min}$. The mixtures were analyzed by BelPhotonics Ultraviolet/ Visible-M51 (Bel) spectrophotometer at $510 \mathrm{~nm}$ and the flavonoid contents were obtained from a 6-point catechin standard curve.

The contents of total phenolic compounds were obtained according to the methodology described by Untea et al. (2018), with modifications. A $50 \mu \mathrm{L}$ aliquot of the samples was added to $250 \mu \mathrm{L}$ FolinCiocalteu reagent and $2.5 \mathrm{~mL}$ distilled water. The mixture was homogenized for $1 \mathrm{~min}$ and then added to $1.0 \mathrm{~mL} \mathrm{Na}_{2} \mathrm{CO}_{3}(7 \% \mathrm{w} / \mathrm{v})$ and incubated for $1 \mathrm{~h}$ at room temperature. The samples were analyzed by spectrophotometer at $750 \mathrm{~nm}$.
The antioxidant potential of the samples was verified by the cationic free radical discoloration method 2.2'-azinobis (3-ethylbenzothiazoline-6-sulfonic) (ABTS), as a result of neutralization with the antioxidant compounds present in the samples, according to the method performed by Untea et al. (2018). The antioxidant potential of the sample was calculated from a standard curve of the synthetic antioxidant, Trolox, in the concentration range of 0 to 7 nmols.

The blank solutions were prepared for each analysis, consisting of the same reagents specified in each methodology with distilled water replacing the aqueous extract of the acerola or its parts. Statistical analyses were performed by analysis of variance (ANOVA), followed by the Tukey test with $P \leq 0.05$ and were correlated by the Pearson Method with $P \leq 0.01$.

\section{RESULTS AND DISCUSSION}

The average $\mathrm{pH}$ values obtained from whole acerola juices, obtained from different liquefying times and during $72 \mathrm{~h}$ of storage, ranged from 3.41 to 3.57 (Figure 1), while pulp extracts ranged from 3.47 to 3.48 , and seeds from 4.44 to 4.45 (Table 1).

The $\mathrm{pH}$ range of the aqueous extracts of whole fruits and pulp was similar to those obtained by Nascimento et al. (2018), with a pH of 3.35 for industrially obtained acerola pulp and 3.63 for artisanal pulp, and by Caetano et al. (2012), with a pH of 3.47 for juice and 3.44 for pulp. Seed and pulp extracts showed no significant difference in the $\mathrm{pH}$ value regarding the different liquefying times (Table 1).

The mean titratable acidity values ranged from 0.27 to $0.32 \mathrm{~g}$ of citric acid/100 mL of whole acerola extract (Figure 2). The liquefying time significantly interfered, with the lowest values observed in the extracts with shorter liquefying time obtained from the whole acerola and its parts: seeds $(0.08$ to $0.10 \mathrm{~g}$ citric acid $/ 100 \mathrm{~mL})$ and pulp ( 0.32 to $0.34 \mathrm{~g}$ citric acid $/ 100 \mathrm{~mL}$ ) (Table 1$)$. The refrigerated storage of the whole acerola extracts did not significantly alter the titratable acidity (Figure 2).

The mean titratable acidity values obtained in the present study were lower than those reported by Freitas et al. (2006), which ranged from 0.53 to $2.27 \mathrm{~g}$ citric $\mathrm{acid} / 100 \mathrm{~g}$ fruit, and by Caetano et al. (2012) who analyzed whole juice and fruit pulp, obtaining average results of 0.84 and $0.94 \mathrm{~g}$ citric acid/100 $\mathrm{g}$, respectively. It is important to highlight that in both works the results were expressed by $100 \mathrm{~g}$ of pulp or whole fruit juice, which differs from those recorded in the present work. 


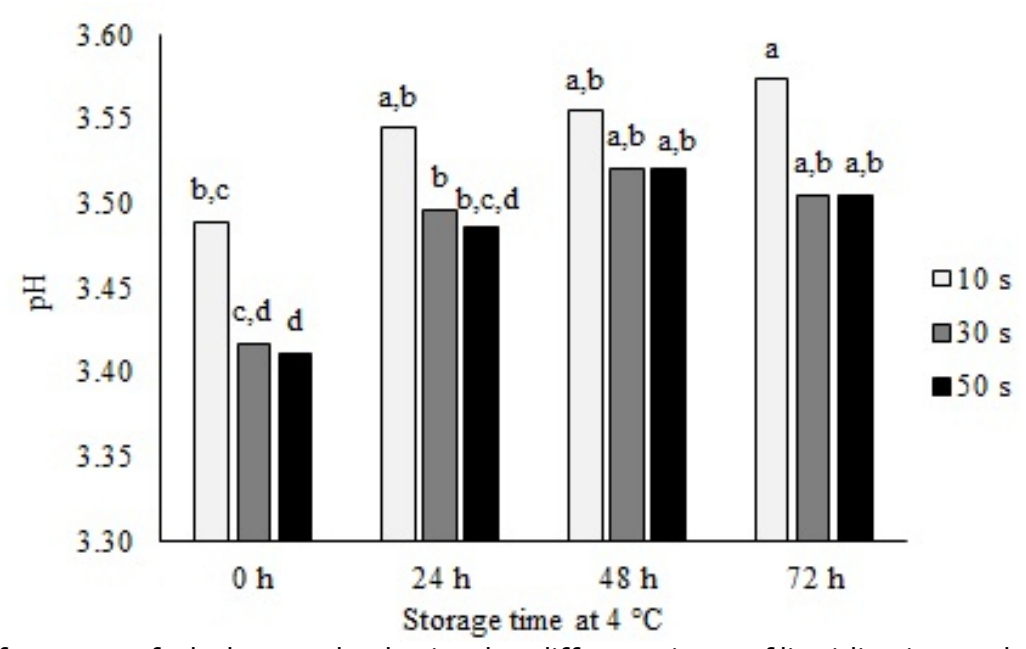

Figure 1: $\mathrm{pH}$ values of extracts of whole acerola obtained at different times of liquidization and stored at $4{ }^{\circ} \mathrm{C}$ for $72 \mathrm{~h}$.

Table 1: pH values, total titratable acidity, contents of phenolic compounds, flavonoids and antioxidant potential in acerola seed extracts and pulp juices obtained from different liquefying times.

\begin{tabular}{ccccccc}
\hline Part & $\begin{array}{c}\text { Liquefying } \\
\text { time }\end{array}$ & $\mathrm{pH}$ & $\begin{array}{c}\text { TTA }(\mathrm{g} \text { citric } \\
\text { acid/100 mL) }\end{array}$ & $\begin{array}{c}\text { Phenolic compounds } \\
(\mathrm{mg} \mathrm{GAE} / 100 \mathrm{~mL})\end{array}$ & $\begin{array}{c}\text { Flavonoids } \\
(\mathrm{mg} \mathrm{CE} / 100 \mathrm{~mL})\end{array}$ & $\begin{array}{c}\text { Antioxidant potential } \\
(\mathrm{mmol} T E / 100 \mathrm{~mL})\end{array}$ \\
\hline \multirow{4}{*}{ Seed } & 10 & $4.44 \pm 0.01 \mathrm{a}$ & $0.08 \pm 0.01 \mathrm{~d}$ & $26.06 \pm 1.18 \mathrm{c}$ & $11.17 \pm 0.96 \mathrm{e}$ & $0.12 \pm 0.01 \mathrm{~b}$ \\
& 30 & $4.45 \pm 0.01 \mathrm{a}$ & $0.09 \pm 0.01 \mathrm{c}, \mathrm{d}$ & $34.03 \pm 5.89 \mathrm{~b}, \mathrm{c}$ & $28.46 \pm 1.33 \mathrm{~b}$ & $0.15 \pm 0.01 \mathrm{~b}$ \\
& 50 & $4.45 \pm 0.01 \mathrm{a}$ & $0.10 \pm 0.01 \mathrm{c}$ & $44.12 \pm 1.73 \mathrm{~b}$ & $49.45 \pm 1.43 \mathrm{a}$ & $0.18 \pm 0.01 \mathrm{~b}$ \\
\hline \multirow{4}{*}{ Pulp } & 10 & $3.48 \pm 0.01 \mathrm{~b}$ & $0.32 \pm 0.01 \mathrm{~b}$ & $159.84 \pm 9.81 \mathrm{a}$ & $20.19 \pm 2.18 \mathrm{~d}$ & $3.56 \pm 0.40 \mathrm{a}$ \\
& 30 & $3.47 \pm 0.01 \mathrm{~b}$ & $0.34 \pm 0.01^{\circ}$ & $156.17 \pm 4.69 \mathrm{a}$ & $19.28 \pm 1.14 \mathrm{~d}$ & $3.57 \pm 0.26 \mathrm{a}$ \\
& 50 & $3.48 \pm 0.01 \mathrm{~b}$ & $0.33 \pm 0.01 \mathrm{a}, \mathrm{b}$ & $148.49 \pm 3.64 \mathrm{a}$ & $24.30 \pm 1.31 \mathrm{c}$ & $3.44 \pm 0.12 \mathrm{a}$ \\
\hline
\end{tabular}

Leg.: TTA: total titratable acidity; GAE.: gallic acid equivalents; CE.: catechin equivalents; TE.: Trolox equivalents. Values from the same column with the same letter are not significantly by ANOVA and Tukey Test $(P \leq 0.05)$.

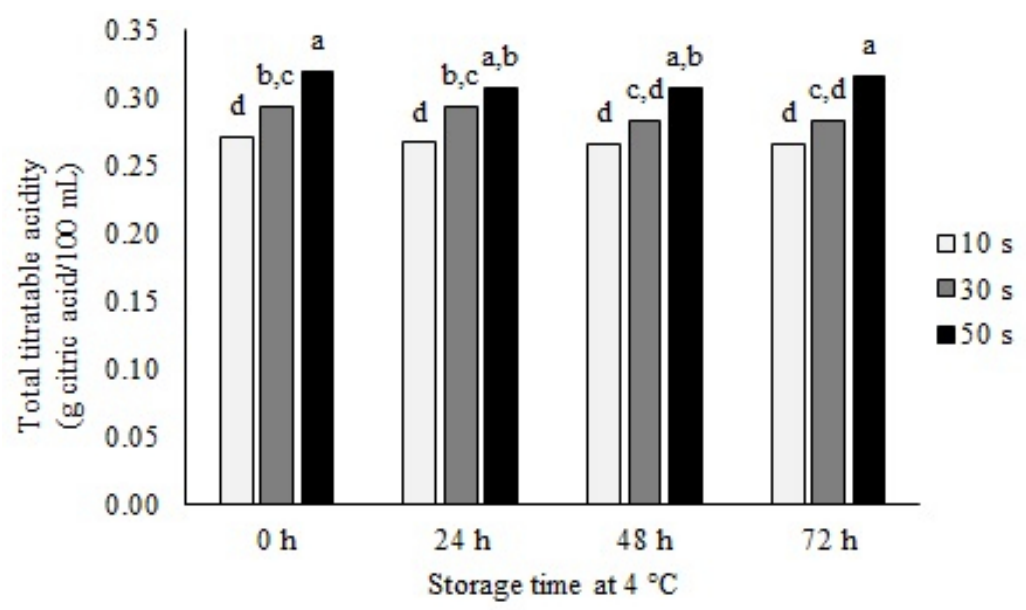

Figure 2: Total titratable acidity expressed in g of citric acid/100mL of whole acerola extracts obtained at different liquefying times and stored over $72 \mathrm{~h}$. 
The total phenolic content ranged from 103.22 to $168.34 \mathrm{mg} \mathrm{GAE} / 100 \mathrm{~mL}$ aqueous extract of whole acerola obtained at different liquefying times over the $72 \mathrm{~h}$ of refrigerated storage (Figure 3).

The different liquefying times did not significantly affect the content of total phenolic compounds when analyzed immediately after obtaining the whole fruit extracts. However, throughout the 24, 48 and $72 \mathrm{~h}$ of storage, a significant difference was observed, with the lowest contents linked to the shorter liquefying times.

After $72 \mathrm{~h}$ of storage, phenolic compounds reduced by $26.8 \%, 18.6 \%$ and $7.1 \%$ in the juices liquefied at 10 , 30 and $50 \mathrm{~s}$, respectively. The lower impact of storage on the total phenolic contents observed in the juices obtained with longer liquefying times is possibly associated with the higher acidity and lower $\mathrm{pH}$ of these juices. Cunha et al. (2014) observed the same trend in the stability of ascorbic acid in the juices of various fresh fruits, with the lowest losses in juices that presented higher initial acidity.

The decrease of phenolic compound content can be explained by oxidation reactions influenced by external factors, such as light and average temperature (Righetto; Netto; Carraro, 2005), although biochemical reactions are catalyzed by phenol oxidases. Liquefying acerolas into its juice causes the descompartmentalization of enzymes and its substrates which, after the disruption of plant tissues, come into direct contact, thereby facilitating and increasing enzymatic activity (Ruiz-Rodrigues et al., 2008; Parkin, 2010).

Maia et al. (2007) verified significant losses of anthocyanins during the industrial processing of acerola juice. The authors state that these compounds are considerably unstable and can become degraded by the action of light, temperature, oxygen, metal ions and enzymes. Rosso and Mercadante (2007) observed that high ascorbic acid content is the main cause of the low stability of anthocyanin in acerola, causing condensation of ascorbic acid with anthocyanin carbon 4, resulting in losses of both bioactive compounds.

The extracts obtained from acerola seeds and pulp presented average contents in the range of 26.06 to 44.12 and 148.49 to $159.84 \mathrm{mg} \mathrm{GAE} / 100 \mathrm{~mL}$, respectively. The extracts of seeds liquefied for $10 \mathrm{~s}$ and $50 \mathrm{~s}$ showed a significant difference regarding the average levels of total phenolics, which was not observed in the pulp extracts obtained from different liquefying times (Table 1). These results demonstrate the importance of increasing the fruit liquefying stage at home in order to obtain fruit juice with high content of bioactive compounds.

Figure 4 expresses the flavonoid contents ranging from 22.43 to $35.22 \mathrm{mg} \mathrm{CE} / 100 \mathrm{~mL}$ of whole acerola aqueous extract obtained at different blending times and over $72 \mathrm{~h}$ of storage. The domestic processing significantly interfered with the flavonoid contents, with the highest contents observed with the longest fruit liquefying time. At the end of refrigerated storage of $72 \mathrm{~h}$, it was possible to observe a significant reduction in flavonoid contents only in the extracts obtained from $30 \mathrm{~s}$ of liquefying (Figure 4).

The same trend can be observed for seed and pulp extracts, which increased the flavonoid contents with the increase of the liquefying period. Seed extracts processed at 10 and $50 \mathrm{~s}$ and pulp extracts obtained under the same conditions were 11.17 and $49.45 ; 20.19$ and $24.30 \mathrm{mg}$ $\mathrm{CE} / 100 \mathrm{~mL}$, respectively (Table 1 ).

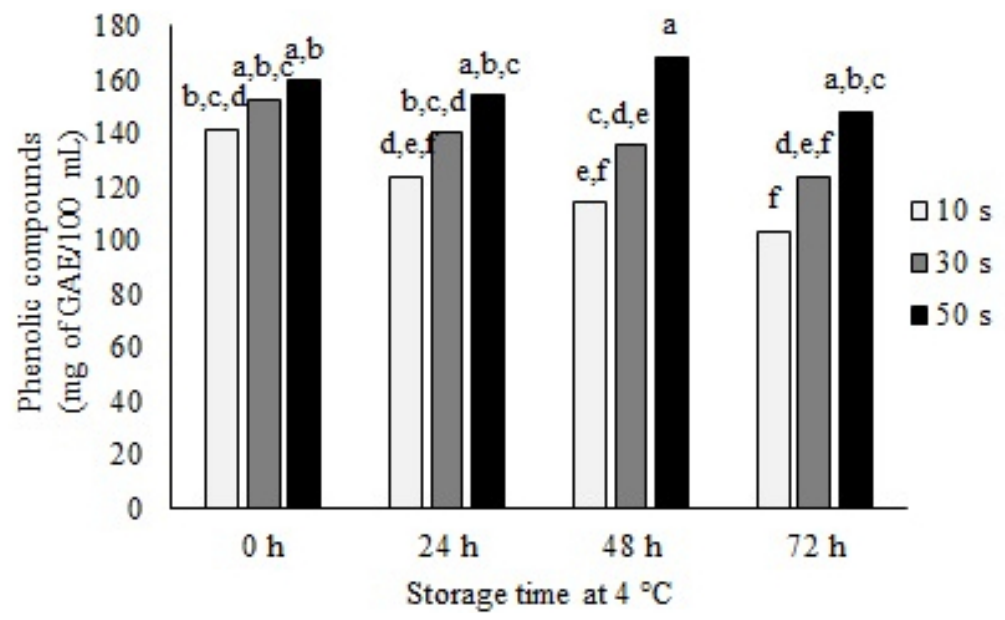

Figure 3: Contents of total phenolic compounds, expressed in $\mathrm{mg}$ of gallic acid equivalents $/ 100 \mathrm{~mL}$ of whole acerola extracts, obtained at different liquefying times and stored over $72 \mathrm{~h}$. 
The antioxidant potential of aqueous extracts of whole acerola ranged from 1.77 to $4.26 \mathrm{mmol} \mathrm{TE} / 100$ $\mathrm{mL}$ of the sample. Fruit processing time as well as storage significantly changed this parameter. The longer the liquefying time, the higher the antioxidant potential and the longer the storage period, the lowest activity (Figure 5).

The juices obtained by longer liquefying showed less reduction of antioxidant activity at the end of 72 $\mathrm{h}$ of storage, corresponding to $17.6 \%$, while the juices liquefied for 10 and $30 \mathrm{~s}$ showed loss of $44.2 \%$ and $44.2 \%$, respectively. The antioxidant activity in acerola juices is directly related to the content of phenolic compounds and ascorbic acid (Belwal et al., 2018).
In the extracts of acerola seeds and pulp, the antioxidant potential ranged from 0.12 to 0.18 and from 3.45 to $3.57 \mathrm{mmol} \mathrm{TE} / 100 \mathrm{~mL}$, however, the liquefying time did not significantly change this parameter (Table 1).

In Pearson regression and correlation analysis, positive correlations were demonstrated, between antioxidant potential and total phenolic compound contents in whole acerolas $(\mathrm{r}=$ $0.76, P \leq 0.01)$ and seeds $(\mathrm{r}=0.88, P \leq 0.01)$, for antioxidant potential and total flavonoid contents in extracts of whole acerolas $(\mathrm{r}=0.43, P \leq 0.01)$ and seeds $(\mathrm{r}=0.99, P \leq 0.01)$ and for the contents of phenolic compounds and total flavonoids in whole fruit $(\mathrm{r}=0.61, P \leq 0.01)$ and seed extracts $(\mathrm{r}=0.92$, $P \leq 0.01)$. Acerola pulp extracts did not show significant correlations between the evaluated parameters.

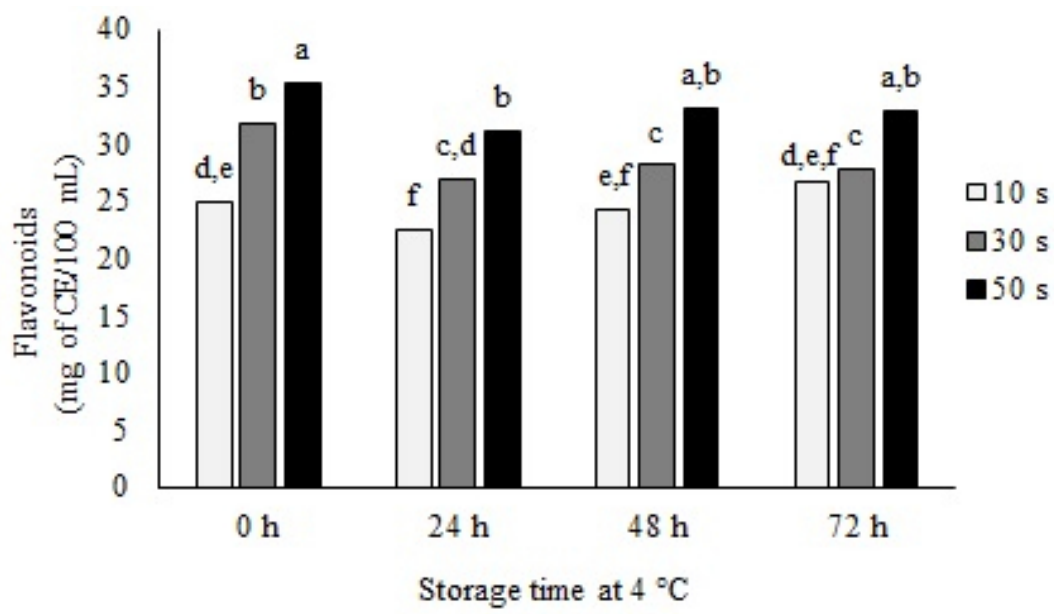

Figure 4: Flavonoid contents, expressed as $\mathrm{mg}$ of catechin equivalents $/ 100 \mathrm{~mL}$ of whole acerola extracts obtained at different liquefying times and stored over $72 \mathrm{~h}$.

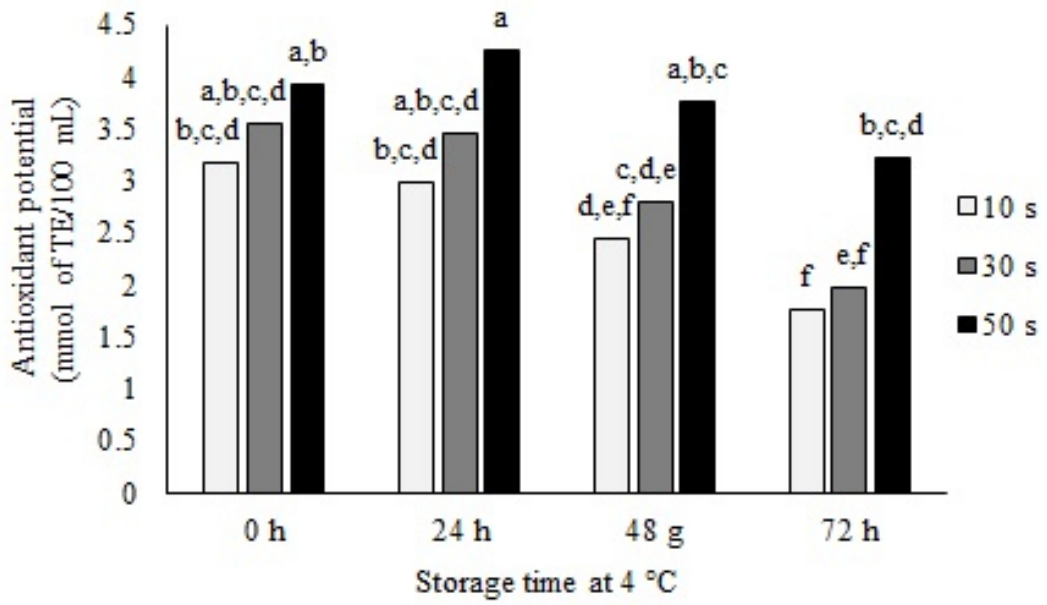

Figure 5: Antioxidant potential, expressed in $\mathrm{mmol}$ trolox equivalents $/ 100 \mathrm{~mL}$ whole acerola extracts obtained at different blending times and stored over $72 \mathrm{~h}$. 


\section{CONCLUSIONS}

Liquefying time and storage are determinant variables in the intensity of the functional properties of acerola juice. The liquefying time of the whole fruit for $50 \mathrm{~s}$ and the immediate consumption, or during the first $24 \mathrm{~h}$, were the best, out of the conditions tested in the present study, for obtaining a juice with a high content of phenolic compounds and antioxidant activity. The acerola seed presents different physicochemical parameters than those of the pulp and the extracts obtained with $50 \mathrm{~s}$ of liquefying time presented higher flavonoid contents, even when compared to fruit pulp extracts, thus reinforcing the potential of using acerola seeds in the preparation of food products claiming functionality.

\section{ACKNOWLEDGEMENTS}

We thank CNPq (Conselho Nacional de Desenvolvimento Científico e Tecnológico) for providing scholarship and Fapemig (Fundação de Amparo a Pesquisa do Estado de Minas Gerais) for financial support (APQ00424-18).

\section{REFERENCES}

AGOSTINI-COSTA, T. S. da.; ABREU, L. N. de; ROSSETTI, A. G. Efeito do congelamento e do tempo de estocagem da polpa de acerola sobre o teor de carotenoides. Revista Brasileira de Fruticultura, 25(1):56-58, 2003.

ASSOCIATION OF OFFICIALANALYTICAL CHEMISTS-AOAC. Official methods of analysis, 16th ed. Arlington, 1995, 1018p.

BELWAL, T. et al. Phytopharmacology of acerola (Malpighia spp.) and its potential as functional Food. Trends in Food Science \&Technology, 74:99-106, 2018.

CAETANO, P. K.; DAIUTO, E. R.; VIEITES, R. L. Característica físico-química e sensorial de geleia elaborada com polpa e suco de acerola. Brazilian Journal of Food Technology, 15(3):191-197, 2012.

CHAVES, M. C. V. da. et al. Caracterização físico-química do suco de acerola. Revista de Biologia e Ciências da Terra, 4(2):1-11, 2004.

CORRÊA, C. V. et al. Influence of ripening stages on physicochemical characteristics of acerola fruits. Revista de Ciências Agrárias, 40(4):808-813, 2017.

CUNHA, K. D. et al. Ascorbic acid stability in fresh fruit juice under different forms of storage. Brazilian Journal of Food Technology, 17(2):139-145, 2014.
HO, C. T.; RAFI, M. M.; GHAI, G. Substâncias bioativas: Nutracêuticas e tóxicas. In: DAMODARAN, S.; PARKIN, K. L.; FENNEMA, O. R. Química de Alimentos de Fennema. $4^{a}$ Edição, Porto Alegre, 2010, p.585-608.

FREITAS, C. A. S. et al. Acerola: Produção, composição, aspectos nutricionais e produtos. Revista Brasileira de Agrociência, 12(4):395-400, 2006.

GOMES, J. E. et al. Morfologia floral e biologia reprodutiva de genótipos de aceroleira. Scientia Agricola, 58(3):519-523, 2001.

GÓMEZ-MEJÍA, E. et al. Citrus peels waste as a source of value-added compounds: Extraction and quantification of bioactive polyphenols. Food Chemistry, 295:289-299, 2019.

ITIS - Integrated Taxonomic Information System. Available in: <http://www.itis.gov>. Access in: October, 31, 2019.

LEFFA, D. D.; SILVA, J. da. et al. Acerola (Malpighia emarginata DC.) juice intake protects against oxidative damage in mice fed by cafeteria diet. Food Research International, 77(parte3):649-656, 2015.

MAIA, G. A. et al. Efeito do processamento sobre componentes do suco de acerola. Ciência e Tecnologia de Alimentos, 27(1):130-134, 2007.

NASCIMENTO, J. F. do. et al. Análise físico-química de polpas de acerola (Malpighia glabra L.) artesanais e industriais congeladas. Pubvet Medicina Veterinária e Zootecnia, 12(6):1-6, 2018.

PARKIN, K. L. Enzimas. In: DAMODARAN, S.; PARKIN, K. L.; FENNEMA, O. R. Química de alimentos de fennema, $4^{a}$ ed., Porto Alegre, Ed. Artmed, p.263-342, 2010.

PEREIRA, C. T. M. et al. Obtenção, caracterização físicoquímica e avaliação da capacidade antioxidante in vitro da farinha de resíduo de acerola (Malpighia glabra L.). Acta Tecnológica, 8(2):50-59, 2013.

RIGHETTO, A. M.; NETTO, F. M.; CARRARO, F. Chemical composition and antioxidant activity of juices from mature and immature acerola (Malpighia emarginata DC). Food Science and Technology International, 11(4):315-321, 2005.

RUIZ-RODRIGUES, A. et al. Effect of domestic processing on bioactive compounds. Phytochemistry Reviews, 7:345384, 2008.

ROSSO, V. V.; MERCADANTE, A. Z. The high ascorbic acid content is the main cause of the low stability of anthocyanin extracts from acerola. Food Chemistry, 10(3):935-943, 2007. 
SIMÃO, S. Cereja das Antilhas. In: SIMIÃO, S. Manual de fruticultura. São Paulo: Agronômica Ceres, 1971, p.447485.

UNTEA, A. et al. Comparison of ABTS, DPPH, phosphomolybdenum assays for estimating antioxidant activity and phenolic compounds in five different plant extracts. Bulletin UASVM Animal Science and Biotechnologies, 75(2):111-114, 2018.

VASAVILBAZO-SAUCEDO, A. et al. Phytochemical characterization and antioxidant properties of the wild edible acerola Malpighia umbellata Rose. CyTA - Journal of Food, 16(1):698-706, 2018. 